\title{
Özofagus buji dilatasyonu sırasında görülen bir komplikasyon, kılavuz telin mide içerisinde düğümlenmesi
}

\author{
An unusual complication seen during the esophagus bougie dilation; tangling of the guide wire in \\ the stomach
}

Burçak Evren TAŞDOĞAN, Yüksel GÜMÜRDÜLÜ

Çukurova Üniversitesi Tip Fakültesi Gastroenteroloji Bilim Dalı, Adana

\begin{abstract}
GİRISS
Endoskopik işlemler eşliğinde yapılan terapötik girişimler birçok olguda hastaları ciddi mortalite ve morbiditeye neden olabilecek cerrahi girişimlerden koruyarak tedavi şansı sağlamaktadır. Fakat bu endoskopik terapötik işlemlerin de kanama, perforasyon gibi birçok komplikasyonu bulunmaktadır (1). Burada endoskopik özofagus buji dilatasyonu sırasında gelişen ve klinik pratikte ilk kez karşımıza çıkan bir problem ve bu problemin çözümünden kısaca bahsedeceğiz.
\end{abstract}

\section{OLGU}

Altmışaltı yaşında bir kadın hasta hastanemiz Gastroenteroloji Polikliniğine son üç aydır olan yutma güçlüğü nedeniyle başvurdu. Öncesinde bilinen osteoporoz ve depresif bozukluk tanıları olan ve medikal tedavi kullanan hastanın hem katı hem sıvı gıdalarla yutma güçlügü olmaktaydı. Kilo kaybı tariflemeyen hastanın yapilan rutin kan tetkikleri normal sinırlarda saptandı. Hastanın üst gastrointestinal sistem endoskopisi yapıldı, özofagus 15. cm'de benign natürde gastroskopun geçişine izin vermeyen darlık alanı tesbit edilerek buraya buji dilatasyonu uygulanması planlandı. Darlık alanından distale klavuz tel gönderilerek sirasiyla 9, 11 ve 13 mm'lik bujilerle darlık alanına dilatasyon uygulandı. Kontrol gastroskopi yapılmak üzere kılavuz tel çekilerek çıkarılmak istenildiğinde telin takıldığı ve dışarıya çıkmadığı izlenerek tel yerinde bırakılarak mideye endoskop ile girildi. Mide içerisinde kılavuz telin düğümlendiği görüldü (Resim 1). Bunu üzerine gastroskop üzerinden overtube geçirilip dügümlenmiş olan kılavuz tel overtube'un içerisine alınarak çıkarıldı. Darlık alanının kontrolünde burada endoskopun geçişine rahatlıkla izin veren yırtık alanının oluştuğu izlendi.

\section{SONUC}

Özofagus darlıklarının dilatasyonu sırasında perforasyon, kanama, şiddetli ağnı ve bakteriyemi gibi komplikasyonlar orta- ya çıkabilmektedir (2). Kılavuz telin mide içerisinde dügümlenmesi ise bu olgu ile klinik pratikte ilk kez karşımıza çıkmış bir komplikasyon olup manipülasyon güçlügü yaratmıştır. Literatürde, erişebildiğimiz kadarıyla, böyle bir komplikasyon bildirilmemiştir. Kılavuz telin distale çok uzun miktarda gönderilmesinin bu probleme neden olduğunu düşünmekteyiz. Kılavuz tel gelmediğinde eğer daha güçlü bir şekilde çekilse idi perforasyon, kanama gibi komplikasyonlara neden olabilirdi. Telin çekerek çıkarılması bu komplikasyonlara neden olabileceğinden overtube kullanılarak çıkarılması hastaya zarar vermemizi önleyerek problemi çözümlemiştir.

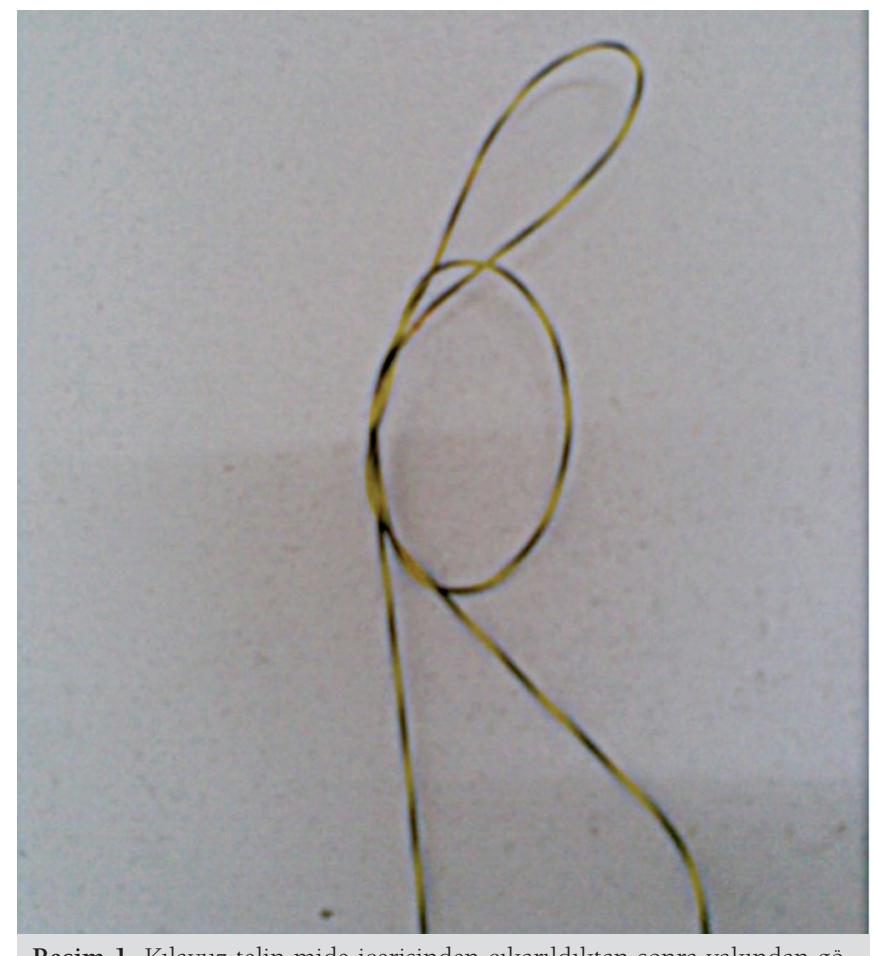

Resim 1. Kılavuz telin mide içerisinden çıkarıldıktan sonra yakından görünümü 


\section{KAYNAKLAR}

1. Eisen GM, Baron TH, Dominitz JA, et al. American Society For Gastrointestinal Endoscopy. Complications of upper GI endoscopy. Gastrointest Endosc 2002; 55: 784-93
2. Clouse RE. Complications of endoscopic gastrointestinal dilation techniques. Gastrointest Endosc Clin N Am 1996; 6: 323-41. 